\title{
RELIEF FROM DOUBLE TAXATION OF PERSONAL INCOMES
}

John MacArthur Maguire

When an individual learns that his income is being subjected to or threatened with double taxation, ${ }^{1}$ he usually goes to a lawyer to find out whether the taxing states ${ }^{2}$ are overreaching themselves. So far as strict jurisdictional rules go, this hope is often disappointed. But under present circumstances the inquiring client may be given the cheering information that public interests are arrayed on his side and that one or the other of, or perhaps even both, the states concerned will voluntarily do something to lessen his troubles. The great ebb of wealth which has turned so many of the larger European nations from creditors into debtors has forced these nations to face the necessity of readjusting their fiscal systems to attract foreign capital. For the present, the United States holds the opposite position. Our interest lies in planning and executing a policy which will encourage foreign investment by American business men. An important item of governmental policy in both the European and the American positions will be common-sense limitation of taxes upon the profits of international transactions. And it is well for us to study two sides of the question. Some day the financial tide may turn. If it does, we should be forearmed by knowledge of the practical inducements to offer investors from abroad.

This paper, therefore, begins by outlining briefly such jurisdictional limits as tend to defeat or curtail double income taxation, and continues with a summary of the principal voluntary limitations practised or suggested in the British Empire and the United States. It bears, of course, upon both international and interstate property ownership and commercial dealings. It does not, however, consider the double taxation of corporate income. That is a special problem, because the artificial creation and existence of corporations render them peculiarly vulnerable to excise taxes.

\section{I}

\section{RELIEFS DEPENDING UPON LIMITATIONS OF JURISDICTION}

It is best to move from the known to the unknown, opening with a

${ }^{1}$ Only a little ingenuity is needed to conjure up cases of triple or even quadruple taxation of income. But the double tax is bad enough without further refinements of fiscal torture. The term "double taxation" is used colloquially throughout this article. Some authorities distinguish double taxation from duplicate taxation on the ground that both parts of a double tax must be levied by the same state. This distinction is not generally respected and serves no particularly useful purpose in the present connection.

"For convenience, the term "state" when used herein uncapitalized refers to any state or nation. When capitalized, it refers to one of the United States.

[757] 
concise statement of the jurisdictional principles controlling the old familiar personal, property, and excise taxes. ${ }^{3}$

(I) A state (meaning by this term not only a nation but also any of our forty-eight States) may impose a personal tax upon any person domiciled in its territory. A nation may also impose such a tax upon any of its citizens or subjects, irrespective of his domicile. ${ }^{4}$ A personal tax based upon nationality may probably be measured by the entire wealth of the taxpayer, no matter what its nature or where it happens to be situated. A personal tax based purely upon domicile may be measured by the entire wealth of the taxpayer, excluding foreign realty; our States must exclude also certain personalty having an independent foreign situs.

(2) Quite apart from questions of nationality or personal domicile, - a state may levy property tax upon all land and chattels situated within its boundaries, and also upon such intangible property as in contemplation of law possesses a local situs within these boundaries.

(3) A state may tax by way of excise the privilege of acting within its boundaries or taking benefits from its laws.

From this summary, it is obvious that even in the old days there were many possibilities of double taxation where a state line fell between a taxpayer's domicile and his property or business. But comparatively lax administration greatly diminished the risk in practice. The modern income levies are administered impartially and on the whole with strictness. So, if the foregoing rules apply to them, they are bound to result in many overlapping assessments. How far can the rules be accepted still, and in what respects and why must we depart from them?

One plain and relevant ground of distinction between the income tax and the earlier taxes on persons and property lies in the fact that a stream of income cannot be measured at a single instant. Its accrual and receipt involve a time element-a space as distinguished from a point. The former practice was to assess persons and property on a given day, and the resulting tax was usually either valid or invalid as a whole. When dealing in terms of income, neither state nor taxpayer can rest comfortably upon such static principles. Each party must trace the jurisdictional conditions throughout the taxable period. Not infrequently situations arise under which the adversaries must divide

\footnotetext{
${ }^{3}$ See as general authority for the following paragraphs of the text Professor Beale's clear, comprehensive, and concise analysis in Jurisdiction to Tax (1919) 32 HARv. L. REv. 587. Occasional departures from these rules occur. Take, for example, Alaska Packers' Association v. Hedenskoy (I920, C. C. A., gth) 267 Fed. 154, certiorari denied (1920) 254 U. S. 652, 4I Sup. Ct. 149; the case is keenly analyzed in Notes (I92T) 34 Harv. L. Rev. 542, 543.

'Professor Beale's article referred to by the preceding note does not cover this point explicitly. See, however, the same author's later article on The Jurisdiction of a Sovereign State (I923) 36 HARv. L. REv. 24I, 252. Authority is scanty, but there is little or no reason to doubt the soundness of the statement in the text. See last reference, infra note 16.
} 
the bone of contention. Thus courts are enabled in some degree to prevent both tax dodging and double taxation. ${ }^{5}$

Passing beyond this clear difference, one finds that the furious battle of definition in and about the Pollock case $^{6}$ has shrouded the income tax with a haze of mystery from which it is only slowly emerging. There have been and apparently still are persons who think this tax sui generis-who contend, for instance, that a state may validly assess income only when its source is situated and its recipient is domiciled within that state's borders. ${ }^{7}$ At the other extreme we find eminent authorities resolutely trying to replace mystery with too great simplicity by seeking to identify the income tax with some single aspect only of old-fashioned taxation: The United States Supreme Court would stuff it into a show case labeled "Excise." Massachusetts judges would tear this label off and replace it with one of their own reading

This possibility of doing justice has not yet been fully worked out. Administrative officials having to do with income taxes feared that where a State's jurisdiction was made to depend upon domicile, at any time during a period of say six months, double taxation was certain to occur if persons moved in from another State with a similar jurisdictional rule. I3 National Tax Association, Proceedings (I920) 278. It was therefore advocated that a single day should be picked out and unanimously agreed upon as the sacred moment for determining jurisdiction. But in Hart v. Tax Commissioner (I92I) 240 Mass. 37, I32 N. E. 62I, the sixmonth rule received a heavy blow. In Notes (I922) 35 HARv. L. REv. 876, the belief is expressed that the protection here given will be broadly extended. Another case involving a refinement of the problem is now pending before the Massachusetts Supreme Judicial Court. New York by its Laws, x922, ch. 425, has adopted an express provision covering change of domicile during the tax year. Under the Federal Revenue Act of I92I, Act of November 23, I92I (42 Stat. at L. 227), a one-day rule has been promulgated. Regulations 62 (Ig22) art. 3 II3. But it is not altogether easy to find an adequate statutory basis for this rule.

'Pollock v. Farmers' Loan and Trust Co. (1895) I57 U. S. 429, I5 Sup. Ct. 673; s. c. (I895) I58 U. S. 60I, 15 Sup. Ct. 9I2.

${ }^{2} \mathrm{Mr}$. Justice McReynolds may have entertained this theory. He took no part in DeGanay v. Lederer (I9r9) 250 U. S. $376,383,39$ Sup. Ct. 524, 526, where the court sustained a tax upon the income of a foreigner derived from securities lodged in the United States. He dissented in Shaffer v. Carter (I920) 252 U. S. 37, 59, 40 Sup. Ct. 221, 228, which sustained an Oklahoma tax on the income of a nonresident from Oklahoma property. He concurred only in result in Travis v. Yale \& Torme Mfg. Co. (1920) 252 U. S. 60, 82, 40 Sup. Ct. 228, 233, where a New York tax upon the locally earned income of non-residents was overthrown solely because these persons were discriminated against in the matter of exemptions. He dissented in Maguire v. Trefry (1920) 253 U. S. I2, I7, 40 Sup. Ct. 417, 4I9, where a Massachusetts tax on the foreign income of a resident was sustained.

${ }^{8}$ Brushaber v. Union Pacific Ry. (I916) 240 U. S. 1, I6, I7, I9, 36 Sup. Ct. 236, $24 \mathrm{r}, 242$. The fact is that "excise" as here used comes from words which meant not a specialized kind of tax but any kind of tax. See the history of the term in the New English Dictionary (Oxford, I888-). Besides, under the Federal Constitution "excise" may well include taxes which would elsewhere be classed simply as personal. Thomas v. United States (I904) I92 U. S. 363, 370, 24 Sup. Ct. 305, 306. 
"Property Tax." But, going back to the less clouded vision manifest before the battle of I895, we find in such cases as State Tax on Foreign Held Bonds ${ }^{10}$ plain enough recognition that an income levy may under varying circumstances be identified with any of the three standard taxes. Moreover, the present day Supreme Court does not hesitate to justify imposition of federal tax upon local property income of a nonresident alien by arguments which sustain a property tax and nothing else. ${ }^{11}$ Likewise the Supreme Judicial Court of Massachusetts in time of need supports the Massachusetts tax by personal tax arguments. ${ }^{12}$

The long and short of it is that we are coming to recognize the income tax not as a new kind, but as a new method, of taxation. When we apply this method to a resident or a citizen, we are dealing with a manifestation of the personal tax; when we apply it to foreign-owned local property, with a manifestation of the property tax; when we apply it to a business activity, with a manifestation of the excise tax. This being so, we are driven to assume-subject only to the point of divided jurisdiction indicated above- that wherever double taxation was possible under the old system, it is equally possible and decidedly more likely under the new. We need focus attention only on those points at which double taxation used to break down or be challenged, to see whether the new system in any way mends these jurisdictional gaps.

\section{(I) THE PERSONAL ASPECT OF INCOME TAXATION}

It has frequently been said that a tax upon property and a tax upon its income are not to be differentiated in legal effect. If so, it is a possible consequence that where a state would have to exclude certain property in fixing the measure of a personal tax, it must likewise exclude income from that property. The HARVARD LAw REvIEW ${ }^{13}$ seems to have taken the position that this argument will not pass muster. But some of us still cannot forget the hard-fought Pollock case. Had the contention been valueless, the courts which considered Maguire $v$. Tax Commissioner ${ }^{14}$ might have simplified their opinions. There, however, they saw fit to swing the case on the point that the principal from which the income sprang was of such a nature that it had not acquired,

\footnotetext{
The idea was put strongly in Opinion of the Justices (I9I5) 220 Mass. 6I3, 624,108 N. E. 570, 573, and emphatically repeated in Hart $v$. Tax Commissioner, supra note 5 , at p. 39, I 32 N. E. at p. 622 .

${ }^{10}$ (I872, U. S.) 15 Wall. 300, 3I9. The companion case of Pittsburg, Fort $\dot{W}$ ayne \& Chicago Ry. v. Pentsylvania (1872, U. S.) I5 Wall. 326, note, directly compares income and ordinary property taxes.

${ }^{13}$ DeGanay v. Lederer, supra note 7, at p. 382,39 Sup. Ct. at p. 526 .

${ }^{22}$ Maguire v. Tax Commissioner (I9r8) 230 Mass. 503, 512, 120 N. E. 162, 166.

${ }^{13}$ Notes (I922) 35 HARV. L. Rev. 876, 877, note II.

${ }^{14}$ Supra note I2; also, s. c. (I920) 253 U. S. I2, 40 Sup. Ct. 4I7. For a recent authority possibly relevant and of more explicit character, the reader may consult Gillespie v. Oklahoma (I922) 257 U. S. 50I, 42 Sup. Ct. I7I. See (I922) 35 HARv. L. REv. 889.
} 
and very likely could not acquire, a situs of its own adequate to free the beneficial owner from personal assessment on account of it. Assuming, then, that the question is still open, let us see where the argument for non-taxability leads if it be accepted.

As to income taxation by our States, the result is reasonably simple. States could no longer measure the tax on locally domiciled persons by the amounts of income which these persons received from their foreign realty or from such foreign personalty as comes under the rule of Union Refrigerator Transit Co. v. Kentucky. ${ }^{15}$ As to federal income taxation, the result is more complicated. Since the decisions sustaining the excise on foreign-built yachts, ${ }^{16}$ it has seemed at least likely that the Supreme Court would uphold a federal personal tax, otherwise valid, on a citizen, even if measured by his foreign real estate or chattels. From that surely would follow the validity of a tax measured by the income of the same property. One ground might be that the United States extends at least potential protection to all foreign property of every citizen. But this sounds like logic to support a property tax rather than a personal tax. The latter is based on ability to pay, not upon a quid pro quo in the way of property protection. Yet the peculiar tax under consideration is not strictly a property tax, for plainly it could not be enforced in rem against the foreign property if the owner declined to make voluntary payment. However, one must not forget that the United States can give more extensive personal protection to citizens than can any State. Hence it would seem that an assessment of this kind could become the basis of something in the nature of a personal judgment against even a non-resident citizen, which-if he continued recalcitrant-could be satisfied out of any property of his within this country's boundaries. Of course it would not enable the federal government to pursue property or the owner abroad, since no other nation will lend its courts for the enforcement of our tax laws.

Note that the logic of the last point fails to cover a personal tax measured by the income of a locally resident alien derived from foreign property. The United States will not give such property or its income any sort of protection abroad. Hence with respect to him it might consistently be held that the national income tax should have no greater measure than the income tax of the State within which he is domiciled.

Unluckily for the taxpayer, the matter does not stop here. Unless such action runs foul of a local constitutional provision, it is perfectly possible for a state to tax the income of a resident's foreign property after that income has been remitted to the domiciliary jurisdiction, even

${ }^{15}$ (1905) r99 U. S. 194, 26 Sup. Ct. 36.

${ }^{16}$ Particularly United States v. Bennett (I9I4) 232 U. S. 299, 304, 34 Sup. Ct. 433, 435. See also Atlantic Maritime Co. v. Gloucester (1917) 228 Mass. 519, 526, II7 N. E. 924, 927. Since the text above was written, it has been hold in Cook $v$. Tait (I923, D. Md.) — Fed. - that the federal tax on the foreign income of non-resident Americans is valid. The opinion covers the ground fully. 
though it was temporarily exempt from income tax at the instant it arose. ${ }^{17}$ Whether to call this a personal or a property tax is debatable. It might well be justified under either head.

\section{(2) THE PROPERTY ASPECT OF INCOME TAXATION}

As suggested in the last paragraph, a tax may fall upon income as property. That calls for skilful work by the administrative officials. It is like shooting birds on the wing. Special firearms are required and special retrievers are needed to trace and bring in remittances. At best, an efficiency rather far short of one hundred per cent. is to be expected. Besides, the bird may under some circumstances prove to be shot proof. Witness the dividends paid five or six years ago in the shape of tax exempt Liberty Bonds. ${ }^{18}$ This pleasant mixture of patriotism and thrift failed only because the federal tax was not imposed on income. When an income levy is a property tax, it is distinctly more simple to lay it on the capital from which the income springs, using the latter as a measure and not a subject of taxation. This changes wing shooting into pot-hunting, with the target often quite stationary. ${ }^{10}$

We are then brought to a sure and usually easy question of jurisdiction over property. All doubts which have been settled by practice under the general property tax are as fully settled for this purpose. One common and difficult case is necessarily resurrected, however. May we tax interest paid a foreigner ${ }^{20}$ on an obligation which, if embodied in a specialty, is embodied in one kept outside the taxing state? When the interest is payable at a bank or financial house inside that state taxability may be established. But when payable abroad, none of our States may tax it, unless State Tax on Foreign Held Bonds ${ }^{21}$ has heen more undermined than most critics suspect. Although a legislature may attain a roughly similar result by taxing the obligee's rights

${ }^{17}$ Prior to I9I4 the British income tax distinguished between foreign income of British residents according to whether it was or was not remitted to the United Kingdom. Testimony of Sir Charles Campbell McLeod and Sir Algernon F. Firth before the Royal Commission on the Income Tax (rgrg-rg20). I Royal Comm., Evidence (1919) par. I882, I886; ibid. par. I9r3 et seq.; 3 ibid. par. 8006 . The evidence before and the report by this Commission contain one of the most enlightening discussions of double taxation to be found anywhere.

${ }^{18}$ See "Tax on Liberty Bonds" (I9I7) 3I Opinions of Attorney General, I25; Treasury Decisions, No. 2512. Corporation Trust Co., Fed. Inc. Tax Service (I923) secs. Iro2-III2. The reasoning of this opinion is somewhat hazy.

${ }^{20}$ It has been intimated that constitutional objections make the tax on income as such easier for many American jurisdictions. Notes (I922) 35 HARv. L. REv. 876, 878. But even this tax is not free from such objection, and the balance of convenience is all in favor of the tax on property measured by its income.

${ }^{20}$ Here and generally throughout the article, "foreigner" is used as a simple term to designate a person not so bound to the taxing state by either nationality or domicile as to be subject to its personal taxes. "Paid" is used in the sense of "paid or accrued."

${ }^{21}$ (1873, U. S.) I5 Wall. 300. 
in any domestic property mortgaged to secure the obligation, other circumstances are likely to make such a property tax inadvisable or improper.

It is still doubtful whether State Tax on Foreign Held Bonds indicates a principle which restrains federal taxation. What might have been a decisive case ${ }^{22}$ served merely to confuse the issue. The Supreme Court split into two groups over the Civil War tax measured by the interest paid to foreign holders of bonds issued by domestic 'corporations. One group, consisting of three justices, would have treated the tax as being on the obligees or the obligations. A single member of this group would have held the tax invalid. The other members of the first group went the striking length of saying that no matter how outrageous the tax might seem under general principles of jurisdiction, it did not contravene any express limitation on the federal taxing power, and hence the court could not effectively pronounce it invalid. ${ }^{23}$ The second group, a majority of the court, held that the tax was valid as being levied on the obligors rather than on the obligees or the obligations.

There the matter stands, so far as Supreme Court decisions go. But there has been one significant English decision. ${ }^{24}$ An American railroad company issued to a British trustee an obligation payable in London as to both principal and interest. The contract with the trustee expressly provided that the law of England should govern. A third party to this contract was a British surety for due performance by the obligor. Under the federal revenue act the American company was compelled to impound at the source a certain percentage of its payments to London. It remitted the remainder only, claiming that this fully discharged its obligations. The trustee thereupon sued the surety for the deficit. The court allowed recovery, saying pithily that there was nothing in British statute or common law (or, it might have added, in common sense) which enabled the American corporation to satisfy part of its debt to the English obligee by payment to our federal treasury.

This seems entirely sound. It means fundamentally that our government lacked jurisdiction to impose the tax in question. The test could be made complete if the surety would sue the railroad company in the United States for reimbursement. I am advised that no such suit is contemplated. Surely, though, the point will come up sooner or later if our present tax policy continues, and when it does arise may well result in favor of the foreign obligee.

\footnotetext{
${ }^{22}$ United States v. Erie Railway Co. (1882) I06 U. S. 327, I Sup. Ct. 223. Doctors still disagree on the question. See Treasury Decisions, Nos. 2017, 2313, 23I7, and 2324.

${ }_{23}$ Their opinion was for some reason separately printed and will be found in 106 U. S. 703, I Sup. Ct. 223, 226.

${ }^{24}$ Indian and General Investment Trust, Ltd. v. Borax Consolidated, Ltd. [I920] I K. B. 539, 548-55I.
} 
One other matter bearing upon the property tax aspect of income levies should be noted and considered, although it seems forejudged. Most income taxes are progressive, the rate advancing with each accession to the taxpayer's net income. The justification is that as an individual's revenues rise higher and higher above the amount needed for bare subsistence, he can spare a constantly increasing proportion of the excess for the public needs of the state. Such an argument, finding its sole basis in personal ability, is properly applicable only to a personal tax. What sustains a property tax is an equivalent rendered in the shape of protection. But our assumption here is that no personal jurisdiction exists. And it is the proud boast of our law that the widow's mite receives the same degree of protection as the millionaire's safe-deposit box. How, then, can the state argue its right to tax the latter at a higher rate per unit of value? Should not the progressive principle be confined strictly to those income taxes which have a personal basis?

Right or wrong, it appears almost certain that no constitutional principle may be successfully invoked to force such a result. The case of Shaffer $v$. Carter ${ }^{25}$ seems quite in point, for the tax there was progressive. Then, too, the Supreme Court has already held that a State may levy upon the transfer of the local property of a non-resident decedent a progressive inheritance tax gauged as to its rate by the entire quantity of the dead man's property, wherever situated. ${ }^{26}$ This goes a step beyond what is necessary to maintain a progressive property tax on or measured by income. While the inheritance tax is of course peculiarly favored as being an excise, one feels that the case last mentioned will to some extent bind income as well, particularly as the United States Supreme Court so often calls income taxes "excises." Indeed, one is left wondering whether we might not perhaps run up the rates of our taxes on the local income of non-resident aliens by reference to their aggregate income from every source.

\section{(3) THE EXCISE ASPECT OF INCOME TAXATION}

For present purposes, an excise is to be deemed valid if the act in respect of which it is imposed takes place within the limits of the taxing state, and if the measure of the tax is reasonable. ${ }^{27}$ Certainly where the laws deal with a profitable act the amount of the profit is a reasonable measure. But in those very important cases of local production or local sales by foreigners, it is often difficult to fix the situs of the taxable transaction and to allocate the profit.

\footnotetext{
${ }_{25}$ (1920) 252 U. S. 37, 39, 45, 40 Sup. Ct. 221, 223.

${ }^{2}$ Maxwell v. Bugbee (r9I9) 250 U. S. 525, 40 Sup. Ct. 2. Mr. Justice Holmes led a vigorous dissent, in which the Chief Justice and Justices Van Devanter and McReynolds joined.

${ }^{27}$ In some States constitutional provisions restrict excise taxation to certain classes of acts. It is not within my province to discuss these local provisions.
} 
(A) Sales not Connected with Previous Production. A non-resident sells shares of stock in the New York stock exchange. New York can of course make him pay a fixed excise upon the transfer, without regard to his profit or loss. He has employed a very special localized facility. It is equally obvious that if he made a profit he might, so far as jurisdiction goes, be forced to pay on the spot an additional excise measured by that profit. It would not matter where or how he acquired the stock. But the difficulties of thus collecting this tax without delaying a peculiarly swift-moving business are too formidable. So, whether a foreign seller disposes of his goods on the exchange or in a place less subject to report and regulation, the income excise normally rests upon a periodical return made by himself or by an agent or broker of his. Opportunities for evasion are manifest, but aside from the administrative difficulties thus created the tax is not puzzling. Nor is its measure in any great doubt. So long as the case involves nothing beyond acquisition followed by sale, the state in which the sale takes place may and usually does levy upon the entire profit, whether the acquisition occurred locally or abroad. ${ }^{28}$ Yet it must be admitted that no trader can keep the wolf away from his door unless he knows how to buy cheap as well as sell dear. One might argue that in instances of foreign acquisition part of the ultimate profit should be attributed to the act of purchase and should be taxable only where that occurred. The obvious failure of this argument to command practical acceptance can be taken with calm philosophy, since in the converse situation there is little inclination to attempt a tax on the basis of a shrewd purchase alone. ${ }^{29}$

It is assumed above that the taxing state is the unquestioned "place of the sale." That phrase will bear analysis. At its strongest, it means that the contract is made and delivery and payment also occur where the excise is imposed. Needless to say, international and interstate traders have carefully exploited the situation with an eye to minimizing their expenses. They have found that it is often perfectly possible to close the contract, make the delivery, and collect the purchase money at their own domiciles or business seats. When this is done under proper legal advice, no tax on account of profits becomes payable at what we may term the ultimate destination of the goods. The procedure was developed by an interesting line of British decisions, culminating for the moment in a case decided by the House of Lords last year which brought down with a crash one deliberate attempt to extend the scope of income tax. ${ }^{30}$ The same principle underlies many of our own cases defining the term "doing business."

${ }^{23}$ This rule is put clearly in Revenue Act of r921, supra note 5, sec. 217 (e).

${ }^{20}$ Royal Comm. on Income Tax, Report (1920) par. 54 (a).

${ }^{\infty}$ F. L. Smidth \& Co. v. Greenwood [1920] 3 K. B. 275; s. c. [I921, C. A.] 3 K. B. 583 ; s. c. [I922, H. L.] I A. C. 417 . The significance of this decision appears from paragraphs $47-49$ of the Royal Commission's Report, supra note 29, 
(B) Sales Coupled with Production. Suppose that a non-resident alien trader produces or finishes goods in the United States, exports them to England, and there sells them at a profit. If we try to tax this man, he makes three arguments-two legalistic and one purely practical. He points first to the stock dividend cases as holding that income must be derived from property before it can be taxed..$^{31}$ Now, says he, the obvious effect of these adjudications is to postpone the levying of a tax until the occurrence of the final act of profit realization. That act is the sale. But as the sale is in England, the United States has entirely lost its jurisdiction and therefore loses the chance of adding to its revenue. $^{32}$ Parenthetically, he remarks that we cannot prevent the loss by imposing an export tax, because our federal constitution forbids. ${ }^{33}$ His second theoretical argument is that even if we are allowed to tax him on this transaction, the increase in value from the work on the goods is exactly offset by the cost of the work, so that the tax is nil..34 And third, he asks how our officials intend to exact the tax without crippling commerce by holding an inquest on every outgoing shipment.

It is easiest to answer these objections in reverse order. As to the practical difficulty of applying the tax, the proper and common-sense reply is that we are not striving for unattainable perfection and will impose the levy only upon those who make a fairly regular business of local production followed by export for sale abroad. Such people are reasonably sure to have local agencies, local plants, and local stocks of goods which guarantee the collectability of taxes assessed on an annual basis. As to the point that the cost of the finishing processes equals and offsets the new value thereby added, we can answer that this simply is not so. Why is the work done, unless it puts the exporter in a position to make something over and above his expense? He might, of course, miscalculate and come out sometimes either just even or with a loss to meet, but the bankruptcy court yawns for him if he does so too often. The real manufacturing profit in the case of articles having a regular market is the difference between the price at which the finished goods would be sold by a manufacturer and the aggregate of what has been paid for the original materials and for the various processes to

at p. II. Since this article was written, the case of Alpha Portland Cement Co. $v$. Commonzealth (Ig23) — Mass. —, has unsettled the situation in the United States.

"1 Eisner v. Macomber (x920) 252 U. S. I89, 207, 40 Sup. Ct. 189, 193.

${ }^{32}$ See the opinion of Acting Attorney General Frierson under the Revenue Act of I9I8 (40 Stat. at L. I057), in the course of which he says: "No income is derived from the mere manufacture of goods; before there can be income there must be sale ...." 4 Cumulative Bulletin (192I) 280, 282 (3-2I-I40I; Treasury Decisions, No. 3IIr).

${ }^{83}$ Constitution of the United States (I789) art. If secs. 9 and Io. A. G. Spalding \& Bros. v. Edzwards (April 23, I923) U. S. Sup. Ct., Oct. Term, 1922, No. 710.

${ }^{34}$ Royal Comm. on Income Tax, Report (1920) par. 54 (c), repels one form of this argument. 
which they have been subjected. ${ }^{35}$ Where the market is irregular, and disposition by a manufacturer would involve very special elements of salesmanship, it is more difficult to phrase a rule for determining the profit, but that does not mean that the profit is non-existent.

Now as to the first objection based on the proposition that the profit, if any, is not realized until sale and therefore arises beyond the taxing jurisdiction of the United States. Observe that a distinction is to be taken. The taxpayers who have successfully sheltered themselves behind the necessity for realization have been those whose profit arose or was to arise simply out of the passive ownership of property, and not out of any sort of activity normally subject to an excise tax..$^{36}$ In the immediate case the taxpayer actively carries on a business and thus joins the excisable class. Surely the ultimate manufacturing profit is a reasonable measure of taxation, no matter where it is realized.

What complicates the problem, of course, is that the buying, the selling, and the manufacturing profits are realized simultaneously and in an undivided lump. But this is not a fatal complication. A practical illustration both of the calculation and the temporary suspension of such profits can be found in the operations of the United States Steel Corporation. A series of subsidiary companies carry the metal forward from the mines to its myriad final forms, the various concerns being separated largely under functional standards. Their consolidated financial statement shows the accrued though still unrealized profits held pendant but ready calculated for distribution when the final step is taken. ${ }^{37}$

Despite this illustration, it is probably far beyond the powers of any tax gatherer, and even further beyond the patience of the average foreign trader, to dissect every transaction and segregate each kind of profit. Hence the courts tend to sustain methods by which fair general approximations are attained. For example, the profit attributable to manufacturing might be deemed to bear the same proportion to the total profit that the taxpayer's manufacturing property in the United States bears to his total manufacturing and distributing property both here and abroad. More elaborate mathematical formulae are in actual use. $^{38}$ It is also possible to give the taxpayer at least a choice between

${ }^{25}$ Ibid. par. 55 .

${ }^{*}$ Observe the statement in Flint $v$. Stone Tracy Co. (I9I0) 220 U. S. 107, 150, 3I Sup. Ct. 342, 348, that the Pollock case, supra note 6, construed the income tax of 1894 as being direct "because it was imposed upon property simply because of ownership."

${ }^{37}$ Twenty-first Ammual Report of United States Steel Corporation for Fiscal Year Ended December 3I, 1922, 6 note, 8 note, 23, 33 note, and 35 . Naturally this process of allocation is much easier where the dealings are between legally distinct corporate units than where every stage takes place in a single business concern.

${ }^{33}$ For a decision sustaining in a particular instance a formula like that described above, see Underwood Typezuriter Co. v. Chamberlain (I920) $254 \mathrm{U}$. S. II3, 4I Sup. Ct. 45. The taxpayer was incorporated, but this did not affect the principle 
two evils, by letting him elect to pay a tax on turnover if he does not wish to make the disclosures and perform the calculations required for compliance with one of the tax formulae. ${ }^{39}$

Assume now a variation of the case just put. The non-resident starts with his raw material or unfinished goods as before, but instead of doing the manufacturing or finishing operations himself has them done for him by an American manufacturer. Here, unless the foreigner makes himself a principal by supervision over the details of the processes, it is not altogether easy to see that he brings himself within reach of an excise tax. ${ }^{40}$ Note, though, that even if he personally escapes tax, manufacturers who work for him must pay on the profits they realize from the work. Hence the public revenues are not altogether slighted.

Finally, reverse the point of view and suppose that our non-resident alien manufactures goods abroad and sells them here. This throws us back upon the latter part of the discussion under sales not involving previous production, with a certain additional question about the amount of the profit to be taxed. For even if the sale were unquestionably local to the United States, it might be urged that only the merchandising profit, and none at all of the manufacturing profit, should be liable to assessment by us. It would seem, however, that while approximate separation of manufacturing and merchandising profits may be permitted for the purpose of swelling the revenues in the state where only the manufacturing occurs, it will not be compelled for the purpose of diminishing the revenues in the state where only the sale occurs. Tax law is full of similar failures in reciprocity. ${ }^{41}$

of the case. Regulations 62 (I922) art. 327, sets out the federal formula. See also ibid. art. 327 (a). For New York's formula, consult N. Y. Personal Inc. Tax Regs. (I92I) art. 457. This precise problem cannot arise under the Massachusetts personal income tax law, but that State has an elaborate formula for corporations. Mass. Gen. Laws, 192I, ch. 63 , secs. 38, 4I, and 42. Compare the New York corporation tax in Laws, 1917, ch. 726, sec. 214; amended by Laws, I920, ch. 640, and Laws, I92I, ch. 705, sec. 4. See also the pamphlet issued by the Wisconsin Tax Commission entitled Wisconsin Income Tax Law (5th ed. I922) 38 et seq., and, upon the same point, F. D. Strader's remarks in $1_{3}$ National Tax Association, Proceedings (I920) 318. Two cases of interest are Westby $v$. Bekkedal (I920) I72 Wis. II4, I78 N. W. 45I; and People, ex rel. Stafford, v. Travis (I92I) 23I N. Y. 339, r32 N. E. I09.

${ }^{39}$ Royal Comm. on Income Tax, Report (1920) par. 50, mentions this alternative. Mass. Gen. Laws, I921 ch. 63 , sec. 42 , gives corporations, and $N . Y$. Personal Inc. Tax Regs. (1921) art. 470, gives individuals, a vaguer alternative. Where it can be shown that one of the tax formulae causes actual injustice, relief may be given. Underwood Typewriter Co. v. Chamberlain, supra note 38 .

${ }^{40}$ The British Royal Commission, however, wished to tax the foreigner in this situation. See their Report (r920) par. 54 (c).

"11 Thomas Reed Powell gives an interesting analysis of the matters just covered by the text. See his Indirect Encroachment on Federal Authority by the Taxing Powers of the States (rgrg) 32 HARv. L. REv. 634, 658 et seq. 


\section{(4) SUMMary}

A summary of the discussion thus far is short and sad. The taxpayer who owns property or transacts business in a state or states other than that of his domicile is only too likely to find his income doubly taxable. The domiciliary state can in one way or another levy a practically universal personal assessment; the foreign states can largely overlap this broad tax by assessments on the property or excise bases. Even the progressive or surtax feature may be duplicated.

II

\section{VOLUNTARY RELIEFS FROM DOUBLE INCOME TAXATION}

The question of voluntarily granted exemptions from double income tax is well covered by the various situations in the British Empire and the United States. The choice of the United States for discussion needs no remark or explanation. The reasons for choosing the British Empire are equally persuasive, if not so obvious. The income taxes in the mother country, the Dominions, and the Colonies are cast on familiar models, easily comparable to our own. Moreover, in the Empire we find a great variety of conditions and fiscal needs, and a broad diversity of relations between the member states. Great Britain is closely linked to every Dominion by both sympathetic and political bonds. It is largely through the leadership of the mother country that the various Dominions are connected with one another. Great Britain of course holds a controlling and unifying position so far as the Crown Colonies and protectorates are concerned. ${ }^{42}$ The inter-colonial and inter-dominion relations are often quite distant because of geographical dispersion. Thus we find here a series of political connections running all the way from the closest integration or alliance to something little stronger than bowing acquaintance.

Another important reason for considering the British Empire here is its recent full investigation of double income tax. A Royal Commission thoroughly overhauled the British income tax in I9Ig-x920. ${ }^{43}$ As a result of this Commission's report Parliament took certain steps to prevent burdensome tax duplication between Great Britain and the Dominions and Colonies. These steps in themselves constituted a suggestion that the Dominions having responsible government should also act. About two years later an Inter-Departmental Committee on Income Tax was formed to consider the problems raised by imposition

\footnotetext{
"For a description of the political relations between Great Britain and the other members of the Empire, consult 2 Lowell, The Government of England (5th ed. I920) 386 et seq.

${ }^{4}$ It is impossible in the space available for this article to review the Report of the Commission, let alone the seven volumes of evidence. The student of double taxation or of any other income tax problem can multiply my references to this source.
} 
of tax in Colonies not possessing responsible government. The Committee reported in December, I922.44 Thus the entire field has been carefully and recently canvassed.

In passing, it may be well to point out two minor matters:

Voluntary alleviation of double income tax is sometimes based upon considerations of sympathy for individual hardship. This never has been a very broad basis for relief. Sympathy and taxes do not go well together. For example, the Massachusetts income tax law originally exempted income which residents derived from securities held by foreign administrators, executors, and testamentary trustees, provided these securities were legally taxed in other states. The Supreme Judicial Court took occasion to term this exemption a just one. ${ }^{45}$ Nevertheless after a few years it was repealed, not because the justice of the taxpayer's case had lessened, or even because a great amount of tax was being foregone, but because application of the exemption increased administrative difficulties. Under modern conditions of heavy public debts, large governmental expenses, and consequent ruthless taxation, mere individual hardship is less than ever a compelling plea for alleviation.

It is also true that a certain narrow relief from double income tax is granted purely on the ground of comity. Thus we find the United States refraining from the taxation of income belonging to foreign governments, and their ambassadors, ministers, and consuls. ${ }^{46}$ This exemption is not likely to grow and holds no elements of particular interest.

(I) RELIEF FROM DOUBLE INCOME TAX IN THE BRITISH EMPIRE

The report of the Royal Commission of I9I9-I920 is a notably able document based upon a wide range of evidence from administrative officials, lawyers, accountants, and business men. Primarily, of course, this report refers only to the income tax levied and enforced in the British Isles. But necessarily the recommendations respecting double tax had a complementary reference to the taxes of Dominions, Colonies, protectorates, and foreign nations.

Witnesses before the Commission made numerous proposals respecting multiple taxation. Many argued for diminution or abolition of this hardship within the Empire. Several argued that the relief should be carried further and applied as between Great Britain and foreign countries. $^{47}$ Some in this latter group thought that every foreign

\footnotetext{
"In subsequent notes this report is termed Inter-Departmental Report.

${ }^{45}$ Maguire v. Tax Commissioner, supra note I2.

${ }^{45}$ Revenue Act of Ig2I, supra note 5, sec. 213 (b) (5), and Regulations 62 (I922) art. 86.

${ }^{47}$ Among others, O. E. Bodington, 4 Royal Comm., Evidence (rgrg) par. 14,256;

S. E. Cash, 5 ibid. par. I6,084; Sir Algernon F. Firth, 3 ibid. par. 7667; Ernest

C. Pegler, 7 ibid. par. 26,445 et seq.; and A. M. Singer, 3 ibid. par. 5 I79 et seq.
} 
country ought to be included. Others ingeniously suggested that remission should be extended only to those nations which had been the allies and associates of Great Britain in the world war. The argument in favor of this latter suggestion was that the great burden of modern taxation is due to war expenses and that those who had struggled and suffered on the same side in the conflict should not be made under any circumstances to contribute doubly to settling its bills. ${ }^{48}$

The action recommended by the Royal Commission referred only to double tax within the Empire. Naturally one wonders whether it was not a mistaken policy to confine relief within these limits. Failure, for example, to enter into a reciprocal arrangement with the United States bears heavily upon many British business men and may cause them to change the locations and control of their American businesses so that Great Britain will entirely lose her taxing power over them. However this may be, the limited recommendation has full value for general discussion. The lines of a sweeping exemption from double tax would follow those of the intra-Empire relief.

At the time when the Royal Commission made its investigation the condition of income taxation in the British Empire was somewhat chaotic. Roughly speaking, the United Kingdom levied an income tax similar to the one now levied by our federal government, except that non-resident nationals were not taxed on their foreign income. Residents of Great Britain were taxed upon all their income from whatever source derived; in addition a tax was laid upon all income arising in Great Britain irrespective of the recipient's domicile. ${ }^{49}$ Some Dominions and Colonies followed the same practice. But others had taxes which were much more limited in scope, applying only to income from local sources. ${ }^{50}$ The agitation for relief against multiple or cumulated taxation had been going on for years. In IgI6 "a roughand-ready expedient" was tried, in the form of a provision giving maximum relief amounting at the time to thirty per cent. of the heavy United Kingdom tax in cases where both this and a Colonial tax were imposed upon the same income. ${ }^{51}$

It soon became clear in the hearings before the Royal Commission that this measure of relief must give way to something better. Various new schemes were proposed for application throughout the Empire. They may be listed as follows: 52

${ }^{4}$ Sir Algernon F. Firth phrased this view in the paragraph of his evidence referred to by the immediately preceding note.

"Royal Comm. on Income Tax, Report (I920) Appx. I, par. 8. This is part of the report of a sub-committee appointed to take up the question of double tax within the Empire.

${ }^{50}$ See supra note 49. Ibid. See also E. R. Harrison's summary in 3 Royal Comm., Evidence (I9r9) par. 6337 et seq.

${ }^{11}$ I Royal Comm., Evidence (Igrg) Appx. 7 (c). The reference here is to an historical note on double taxation prepared by the Board of Inland Revenue.

these proposals are phrased in different order and slightly different form by Royal Comm. on Income Tax, Report (1920) Appx. I, par. I3. 
(a) It was proposed that when income was subject to assessment by two members of the Empire that state which imposed the higher rate of tax should collect its full rate and adjust the loss of revenue by payment to the other state.

(b) It was proposed that throughout the Empire income should be charged solely or at least primarily in the state where it arose. Sometimes this suggestion was coupled with a recommendation that the state of the recipient's residence might make a further charge by way of personal tax. In all cases it was urged that the aggregate of the two charges should have a definite limit, several witnesses hoping to establish an equal tax throughout the whole Empire. ${ }^{53}$

(c) As a modification of or supplement to the immediately preceding suggestion it was proposed that the state of residence might tax income originating within it and income remitted to it from another state of origin.

The first proposal broke down thoroughly. There were two principal objections to its adoption. It was said-and with obvious truth-that action along such lines "obscures the independent right of taxation inherent in every State, and may create the false impression that the State is exempting a class of income which it is in fact charging; or that it is contributing towards the revenue of another State." witnesses also showed that the difficulty of making and executing the necessary agreements for such a financial adjustment would be considerable. ${ }^{55}$ Parenthetically it may be observed that such difficulty between two entirely independent nations would be much greater than that anticipated between two members of the British Empire.

The second proposal received very vigorous support. ${ }^{58}$ It represented an attempt to bring about the general adoption of a system already employed in many Dominions and Colonies. As the reader will see later, it now stands a good chance of general adoption so far as Colonial income tax is concerned. The Commission, however, again decided adversely, believing that the proposal involved too serious an infringement upon principles of taxation followed ever since the adoption of the first income taxes. In one most important aspect the income tax contains an essentially personal element and is to be based upon ability to contribute rather than upon jurisdiction over income source. In the particular instance, too, it was of practical importance that the surrender of tax on the part of Great Britain would have been extraordinarily large. The investment of British money in the Colonies is much greater than the investment of Colonial money in the United Kingdom.

\footnotetext{
${ }^{\infty}$ Two such witnesses were William Mosenthal and Julius Auerbach. I Royal Comm., Evidence (I9I9) par. 2168.

${ }_{54}$ Royal Comm. on Income Tax, Report (I920) Appx. I, par. Ig.

${ }^{\star}$ E. R. Harrison, 3 Royal Comm., Evidence (1919) par. 6333; compare Dr. J. C. Stamp, ibid. par. 9826 .

${ }^{50}$ Royal Comm. on Income Tax, Report (1920) Appx. I, par. 2I.
} 
The third proposal did not differ sufficiently from the second to hope for a better reception.

The Inland Revenue then came forward with a proposal which, after modification, ultimately carried the day. This proposal as finally adopted was in essence that where the same income was taxed or taxable both in Great Britain and in a British possession the mother country should give up the equivalent of the Dominion or Colonial tax up to but not exceeding one-half the rate of British tax. ${ }^{57}$ Any further relief was to be given by the Dominion or Colony concerned. The foregoing remedial provision has been made a section of the Finance Act, I920.58

It will be observed that while this suggestion embodied a hint that the Dominions or Colonies should do something generous no actual string was tied to it. It will be noticed further that the form of exemption necessitates identification of the specific income benefited. Under many circumstances such identification may be very difficult. It may also be necessary for the taxpayer, instead of taking his relief by way of anticipatory credit, to secure a refund of part of his tax after payment. The Royal Commission foresaw both these difficulties, but felt that they would have to be faced. ${ }^{59}$ Here I may well anticipate the statement of a useful administrative device suggested by the report of the InterDepartmental Committee on Colonial income tax. ${ }^{60}$ This Committee decided that where such adjustments of exemption had to be made it would be convenient for the Colony involved to have a tax agent in Great Britain. Such an agent presumably would have no peremptory powers, but wherever a taxpayer will lay the facts before him an adjustment can be reached much more easily by conference than by longranged and long-winded correspondence. This seems a sound and workable scheme for adjustment of many difficulties arising from attempts to alleviate double taxation. Nearly any taxpayer with a clear conscience and a clear perception of his own interests will see that it is wise for him to deal openly with the tax agent, even though that agent cannot force him to do so.

We need not trace subsequent proceedings in the Dominion Parliaments. For our purposes it is enough that the Royal Commission wished the Dominions to bear any residual relief. Parliament's action appears to be a ratification of this desire.

With respect to the Colonies further developments are more interesting. The Inter-Departmental Committee above referred to has drafted a model Colonial income tax act. The control of the mother country over Colonial legislation is such that this act may very well replace those

${ }^{27}$ Ibid. par. 70; ibid. Appx. I, par. 26 et seq.

(1920) Io \& II Geo. V, c. I8, sec. 27.

${ }^{\infty}$ This is to be inferred from par. 69 of their Report.

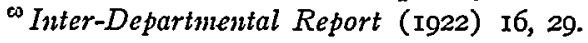


at present in force. ${ }^{61}$ Hence a brief outline of its provisions is desirable.

To begin with, it is significant that the model act taxes only such income as arises within the assessing state and such foreign income as is remitted to that state. ${ }^{62}$ The principle of taxing the person on all his income from every source is thus abandoned. With respect to double taxation the relief recommended bears only upon double taxation within the Empire. As between the taxing Colony and the United Kingdom a scheme supplementing that recommended by the Royal Commission is proposed. The Colony is called upon to grant relief "equal to the amount by which [its] rate of $\operatorname{tax}$. . . . exceeds half the appropriate rate of United Kingdom tax," with half the appropriate United Kingdom rate as a maximum limit. ${ }^{63}$ Thus in the aggregate the individual will pay the higher of the Colonial and British taxes, Great Britain and the Colony sharing the loss fairly equitably. The model act's clauses dealing with double income tax as between one Colony and another, or a Colony and a Dominion, produce the same result. ${ }^{.4}$

If general adoption of the model Colonial income tax is obtained, the British Empire will present an object lesson in the fair adjustment of double income taxes.

\section{(2) RELIEF FROM DOUBLE INCOME TAX IN THE UNITED STATES}

In our own country we find a number of minor reliefs from double income taxation based upon no very general principle. Non-resident aliens, for instance, pay no federal tax upon interest from their bank deposits in the United States, unless they are engaged in business here. ${ }^{.5}$ Obviously it was wiser to make this concession than to have the deposits withdrawn and so lose the chance to tax local banks upon such income as they realize by using foreigners' money. The New York law similarly exempts non-residents, and also exempts them from tax on annuities, bond and certain other interest, and corporate dividends. ${ }^{66}$

Neither thus nor along broader lines can the United States display any such systematic development as that planned and already partly executed among the members of the British Empire. We suffer from both lack of uniformity in State taxation and a strong tendency to ignore foreign taxes or at best to allow them only as deductions from gross income.

It ought, however, to be realized as clearly at home as it is abroad ${ }^{67}$

${ }^{61} 2$ Lowell, op. cit. supra note 42 , at pp. 402 et seq.

"s Inter-Departmental Report (I922) 5, 20.

"Ibid. I3 et seq., 31, 32.

abid. I7, 32, 33 .

${ }^{\text {es }}$ Revenue Act of I921, supra note 5, sec. 2I7 (a) (I).

${ }^{6}$ N. Y. Laws, I9I9, ch. 627 , sec. $359-3$.

" Several witnesses before the Royal Commission spoke with warm praise of our Revenue Act of I9I8, supra note 32, in its bearing upon relief from double taxa- 
that our federal government has treated the international situation with generous wisdom. The Revenue Act of I92I frames an income tax unusually considerate in this aspect. To be sure, this law recognizes State income taxes only as deductions from gross income and not as credits on or set-offs against the United States tax. ${ }^{68}$ But that is fair enough. The federal government and the States discharge functions supposed to be supplementary, not overlapping. The taxpayer is theoretically no worse off when assessed by both these grades of government than he would be if he paid a single governing power for the same service and benefits. A sounder criticism of the Revenue Act of I92I, although a smaller one, is that we do not follow the general custom of exempting income of non-resident citizens derived from foreign sources. ${ }^{69}$

The latter criticism may be met rather effectively by the cold-blooded argument that most Americans are patriotic and that patriotism will stand a good deal. This sort of thing does not usually kill the goose that lays the golden eggs. If we slightly overtax a foreigner who invests money here, he may quite promptly remove his capital and cause us loss. If we somewhat more heavily overtax a locally resident alien on his business in the United States, he may move out. Yet until we overtax a non-resident citizen very heavily indeed he will not cut his national ties and expatriate himself in order to shake off the burden. When commenting upon this part of our tax before the Royal Commission, Mr. E. H. Harrison of the Board of Inland Revenue seemed to think that non-resident Americans were more likely to save themselves by tax-dodging than by expatriation. ${ }^{70}$

The excuse even for tax-dodging is comparatively slight. For any American citizen, resident or non-resident, may credit against the amount of his federal tax such income and other similar taxes as he may have paid during the taxable year to any foreign country or to any possession of the United States. ${ }^{71}$ There is a reasonable limitation upon this credit. Its amount may not exceed "the same proportion of

tion. G. M. Edwardes Jones, 3 Royal Comm., Evidence (I9I9) par. 52 Io et seq. and par. 5379 et seq.; A. M. Singer, 3 ibid. par. 5179; also Sir Frederick Young, I ibid. par. 948 .

${ }^{*}$ Regulations 62 (1922) art. I3I, construing Revenue Act of I92I, supra note 5, sec. 214 (a) (3).

${ }^{\infty}$ Regulations 62 (I922) art. 3, construing the Revenue Act of 1921. An exception is made in the case of certain persons deriving large proportions of their incomes from possessions of the United States. See Revenue Act of I92I, supra note 5, sec. 262. As originally framed, this relief section was much broader and was intended to benefit a class defined as foreign traders. The broad provision passed the House, but fell by the wayside in the Senate.

${ }^{70} 3$ Royal Comm., Evidence (Igrg) par. 6299. The writer feels bound to confess that he has heard of several Americans domiciled abroad who have indicated a desire to trade their original nationality for another one in order to escape tax. But these cases are seemingly rare.

"Revenue Act of I92r, supra note 5, sec. 222 (a) (I). 
the [federal] tax .... which the taxpayer's net income .... from sources without the United States bears to his entire net income. . ."72

A resident alien enjoys the same right in respect of income taxes paid to a United States possession. He enjoys the right in respect of foreign nations' taxes only if his own country allows a similar credit to citizens of the United States residing therein. ${ }^{73}$ This limitation seems somewhat harsh. Aliens resident here can exercise little political pressure upon their home governments. Even the quite large number of English business men in the United States have been unable to bully or blarney Great Britain into acceptance of the reciprocity requirement. ${ }^{74}$

To non-resident aliens the Revenue Act of I921 grants nothing in the way of tax credit. Here, of course, we show ourselves unwilling to apply internationally the British intra-Empire arrangement. Possibly Congress was impressed with the difficulty of allocating a non-resident foreigner's domiciliary tax in order to allow set-off of an appropriate part against our own tax.

Our more serious trouble is with interstate assessments. We may perceive the unsatisfactory condition of State income taxation by glancing at the laws of Wisconsin, Massachusetts, and New York. To a considerable extent the Wisconsin tax is based upon the situs theory. That is, income is assessed if it arises within the borders of Wisconsin and is exempted if it arises outside. ${ }^{75}$ The exemption, however, is much qualified in favor of the taxing State, for residents are required to include as taxable income many important kinds of foreign receipts. Except so far as income goes free on the basis of foreign situs, no relief against double taxation is given, save by a partial deduction of foreign taxes from gross income for purposes of Wisconsin tax.

In Massachusetts the theory of taxation is domiciliary-quite the reverse of the Wisconsin theory. No non-resident is assessed on any income whatever, even though the source be absolutely localized within Massachusetts boundaries. ${ }^{76}$ This clash of theories leads to badly unbalanced relief. A Massachusetts resident deriving income from Wisconsin would be taxed in both States. But a Wisconsin resident deriving income from Massachusetts might well be taxed in neither State. In the matter of allowable deductions and credits the Massachusetts tax is very complicated. ${ }^{77}$ For present purposes it is sufficient

Ibid. sec. 222 (a) (5).

${ }^{3}$ Ibid. (2) (3). Observe that the effect of the credit when allowed is to subject the taxpayer to an aggregate assessment equivalent to the higher of the overlapping taxes. The same end is attained by the British Empire scheme of reliefs. But in the case of an American citizen, we are generous enough to let it be attained entirely at the expense of the United States.

"Regulations 62 (1922) art. 385 .

${ }^{75} \mathrm{I}$ Wis. Sts. I92r, secs. $71.01,71.02$ (3) (c) and (d).

${ }^{7}$ Mass. Gen. Laws, I92I, ch. 62, secs. I, 5, 9-I4, and I7.

"See Mass. Gen. Laws, 1921, ch. 62. Throughout the first part these deductions and credits are scattered helter-skelter. 
to state broadly that Massachusetts allows no credit for foreign income taxes against the rate of her own tax and also that she allows only to a partial extent the deduction of foreign taxes from gross income.

New York presents a different tax from those of Wisconsin and Massachusetts. It proceeds upon a catchall theory reminiscent of the federal income $\operatorname{tax}^{78}$ But in the matter of tax credits there is a curious inversion of federal practice. Only non-residents may have credit for foreign income taxes paid, and not even they except so far as their states of domicile allow New York residents similar rights. ${ }^{79}$ Application of the New York credit provision necessarily requires more or less difficult allocation of taxes. New York does have a consistent and thoroughgoing scheme for allowing deduction from gross income of foreign taxes other than income taxes. ${ }^{80}$ A non-resident claiming such deductions must prove that the foreign taxes are connected with specific taxable income arising in New York.

Nothing more than the foregoing statement is needed to prove the confusion, inconsistency, and injustice already created by competing income laws of the several States. The danger is great that conditions will become worse rather than better. Lawyers, economists, and tax officials have perceived this danger and presented through the National Tax Association carefully thought out proposals for avoiding or alleviating the burden of double income levies. ${ }^{81}$ The proposals thus advanced are based upon scientific separation of the three taxes-personal, property, and excise. It is proposed that a personal income tax should be levied on practically all income from every source by the domiciliary jurisdiction of the taxpayer. This tax is to be progressive. Jurisdictions in which the taxpayer does business are also to levy an income tax of the excise type at a flat rate. If a taxpayer were domiciled and also carried on his business in one State he would pay both these taxes to that State. This system of income taxation is supplemented by a property tax on tangibles at their situs. The draftsmen of these model State acts knew only too well the utter failure of previous efforts to tax intangible property. So they omitted it from the scope of their property tax.

In an ideal world this plan would be most satisfactory. Though three-headed like Cerberus, it would be a tame and discriminating Cerberus. But in the United States it can hardly succeed. To some extent it would collide with State and federal constitutional provisions. The current experience of New Hampshire shows that amendment of

\footnotetext{
${ }^{78}$ N. Y. Laws, I9I9, ch. 627 , sec. 351. See also sec. 359 , amended by N. Y. Laws, I920, ch. 695.

N. Y. Laws, I9I9, ch. 627 , sec. 363 , amended by N. Y. Laws, I920, ch. 691 .

${ }^{80}$ N. Y. Laws, r9I9, ch. 627 , sec. $360-3$ and Ir.

s1 National Tax Association, Proceednngs (I9I9) 435-46r; 6 National Tax Association, Bulletin (I92I) roo et seq., 129. Further discussion will be found in I4 Proceedings (Ig2I) 65-100.
} 
constitutions has not been reduced to an exact science. We cannot count upon systematic revisions to take care of these constitutional hitches. Even if we could, a practical and probably insurmountable objection would remain. Financial and social conditions vary throughout the country. Some States are good residence States and some are not; some States are wealthy, productive, and' fully developed, while others are comparatively undeveloped and in need of foreign capital. It is impossible to expect a uniform surrender of jurisdiction over any sources of taxation.82 Our States always have been and seem likely always to be stoutly independent about the forms and scope of their revenue systems. Mere persuasion will not change them. And we have no such central power as that which exists in the British Empire to force uniformity despite local sacrifices.

\section{CONCLUSION}

Nevertheless it is probably to the method applied in the British Empire that we must look for betterment of our situation. The problem in both cases is similar-more domestic than international. As has been shown, the entering wedge of British double tax reform was a crude makeshift provision giving only partial relief. Steady pressure behind this wedge is leading to the acceptance of a comprehensive system, not based, perhaps, on any theory which would appeal to an economist, but in the long run likely to prove just, satisfactory, and serviceable. With the good example of the federal government as a stimulus, we may find it possible to make headway by working out something like reciprocal business men's agreements between States placed in geographical proximity and having community of business interests. Once that practice starts and succeeds, the very success should attract additional States. It must be admitted that efforts to produce similar interstate harmony as to succession taxes have failed badly. ${ }^{83}$ But no individual or nation ever got ahead by giving up hope because of one failure. The importance of income taxation is reasonably sure to keep on growing. Political constituencies, and in their wake the least impressionable of hard-headed practical politicians, must be brought to realize that governmental finances, and for that matter general governmental success, depend upon a reasonably free flow of capital. Certainly there can be no such free flow unless we at least cut some sluiceways in the double banked income tax barriers along State boundary lines.

\footnotetext{
2 W. G. Roylance of North Dakota spoke out bluntly on this point. I3 National Tax Association, Proceedings (I920) 326.

${ }^{83}$ Irving L. Shaw in 13 National Tax Association, Proceedings (I920) 307, and Nichols, Taxation in Massachusetts (1922) 617-6r9.
} 